International Journal of Advanced Studies in Humanities and Social Science (IJASHSS)

Available online at http://www.ijashss.com

Volume 8, Issue 1 (2019) pp. 13-27

Original Article

\title{
A Survey on the Relationship between Sale, Liquidity and Business Risk with Stock Returns at Companies Listed in Tehran Stock Exchange
}

\section{Mahdi Bagheri', Abolghasem Gholamreza Tehrani2*, Elham Niromand Vojdani aval ${ }^{3}$}

\author{
${ }^{1}$ Assistant Professor, Faculty of Management, Islamic Azad University, Qeshm International \\ Branch, Iran \\ ${ }^{2}$ Corresponding Author, PhD in Business Management, Islamic Azad University, Karaj \\ Branch, Young Researchers Club and Elites, Iran \\ ${ }^{3}$ Master of Business Administration, Islamic Azad University, Karaj Branch, Young \\ Researchers Club and Elites, Karaj, Iran
}

Received: 24 October 2018, Revised: 05 December 2018, Accepted: 20 December 2018

\begin{abstract}
Tehran stock, based on data analysis based on a correlation test and descriptive test run. Descriptive statistics including measures of central tendency and dispersion are independent variables include sales, liquidity and business risk and stock return is the dependent variable According to the findings, investors and capital market participants to sell the sample firms and liquidity ratios have responded. The market capitalization of the company's business risk, and may not, other criteria can be considered in the risk assessment of companies.
\end{abstract}

Keywords: Sale, Liquidity, Business Risk, Stock Returns, Central indicators, Capital Markets, Risk Assessment.

\section{Introduction}

Financial Ratios are one of those tools provided to evaluate the firms by investors mentioned also as a tool for business unit management to evaluate the current status and predict the upcoming status would be occurred in the business unit. These ratios are based on accrual accounting methods get prepared, calculated and extracted. Traditional financial statements reflect information about the cash losses where this is accounted as one of weaknesses of traditional financial statements whereby one can say that accrual accounting basically places the mask on the cash flows of the business. In such a situation, it is assumed lack of necessary information on selling cash flow can distracted the domestic and foreign decision makersconsequently it is reported there exist so many firms have encountered many difficulties in paying their debts despite huge profits. Investors, to predict future cash flow, generally need the information about timing and amount expected for future net cash flows of the business, the risk which might occur in access to cash 
flows, the interest rate used in discounted cash flow (DCF) where on the risk in one perspective can be classified into two classes. The first class are those risks which relate to the internal factors involved in a firm; in every firm, such risks relate to the specific conditions of that firm, not relating to the risk in other firms; as a result, such risk is conveyed as Unsystematic Risk. The second class are those risks not related to one or several firms which relate to the entire market; such risks appear influenced of the return of the entire market conveyed as systematic risk.

\section{Problem Statement}

In present paper, it is asked whether "Sale, Liquidity and Business Risk" influence "Stock Returns" at Companies Listed in Tehran Stock Exchange.

An investor, to attain reasonable return from the stock investing, has to take several measures to choose the stock. Several measures including EPS, DPS, P/g, and etc. exist used mainly by the investors to make decision on investing, thus, other more important problems as follows are neglected beyond this.

Ignoring the company's ability to pay Rate of return and/or Dividends Declared Ignoring the continuity of activities of the company to pay dividends

On the basis of the first problem, it has to be stated that there are so many companies provided with relatively high profitability, but, they do not have sufficient liquidity to pay profit to the stockholders so that paying profit delayed and return of the stockholder by the passage of time exactly due to decrease in liquidity decreases whereby the stockholder would not attain the reasonable return. Basically, while the firms encounter with decrease of liquidity escape through different ways to pay profit to the stockholder, one way is transfer to reserves. However, it might be said that paying profit as said above might lead to Shareholder capital gains increasing productivity, this has to be taken into account that a majority of investors seek to short-term investing gaining more profit in a short duration. If the investor does not attain the desired return, immediately seeks to refrain investing in market or take away what invested previously and investing in unproductive activities, whereby stock exchange reduces and the stock exchange stops booming. Hence, to avoid this, it is necessary the investor in addition to the measures mentioned above as EPS and so forth take into account other measures as the operating liquidity indicators and then goes forward to analyze findings about investment and risk of stocks. Another problem which might be ignored by the investors is the problem beyond continuity of firms' activity. A firm might be provided with high profit and return where on the investor might invest in the stock of that firm in order to gain desired return, but, in the light of continuity of activity of firm questioned so the investor would not gain profit whereas would lose all his investments. Hence, it is better to take into account several measures which indicate the continuity of firm's activities before going through investing on stocks (Ranjbari, 2007).

\section{Research Importance}

Investment is one of the steps necessary in the process of economic growth and development of the country. Investors in supply of capital strive to propel their financial resource to the lowest risk and highest return. Return is possible in form of the annual cash dividends and stock 
price growth. Under normal conditions, an investor buys shares of companies whose profits are high. Sometimes although the firm gains profit, the weakness in the sale of goods or weakness in the timely debt collection might not lead to the desired liquidity. Naturally, without knowledge of the company's financial condition and liquidity of firms and evaluating financial statement, investors might encounter high risk.

Preference to pay share of interest payments instead of dividend and capital gain can state the problems of liquidity of these firms. Hence, use of the information of cash flows and understanding their relations with return of stock in analyses by analysts and investors in investing as well as by managers of these firms can be a good direction in directing the entity towards economic growth and development and optimum resource allocation in a long-term. This paper aims to find a significant relationship between "Sale, Liquidity and Business Risk" and Stock Returns" at Companies Listed in Tehran Stock Exchange, to get to know how much these factors affect the rate of return.

\section{Research Objectives}

An investor, to attain reasonable return from the stock investing, has to take several measures to choose the stock. Several measures including EPS, DPS, P/g, and etc. exist used mainly by the investors to make decision on investing, thus, other more important problems as follows are neglected beyond this.

Ignoring the company's ability to pay Rate of return and/or Dividends Declared

Ignoring the continuity of activities of the company to pay dividends

To conduct this paper, several objectives are taken where the most important ones are as follows:
Find a significant relationship between "Sale, Liquidity and Business Risk" and Stock Returns" at Companies Listed in Tehran Stock Exchange

Collect empirical evidences to get to know to what extent liquidity and business risk ratios get evaluated by investors and analysts.

Importance of liquidity ratios in predicting several aspects of firm's performance

Propose a group of liquidity indicators which can the investors for decision making

\section{Literature Review}

In a study by Dr Nourosh and Abbas Vafadar (1999), a survey on usefulness of accounting information in assessing the risk of market has been provided. In this study, several financial ratios including Net profit to equity ratios, Current assets to current liabilities, Sales to equity and total assets have been taken as Symbols of accounting where their relationship with market risk at 39 Companies Listed in Tehran Stock Exchange has been tested.

Mohammadreza Ahmadi in a study in 2003 examined the relationship between Capital Structure and return of Companies Listed in Tehran Stock Exchange. The statistical population includes 153 firms during 1994-1998 of a variety of industries. The hypotheses of research were tested using regression where the results from findings show that there is not a significant relationship between Capital Structure and return of stock, earnings before income taxes, and Return on equity, whereas a significant relationship exists between Capital Structure and return of Companies Listed in Tehran Stock Exchange (Jamali, 2004).

In a study in 2005, Maryam Salim poor in her thesis approved by Dr Fadaei Nejad, examined the effect of stock liquidity on excess stock return at Companies Listed in 
Tehran Stock Exchange whereby a conclusion has been taken in a way that there is not a significant relationship between stock liquidity and excess stock return (Salim poor, 2005).

In a study by Hamid Haghighat and Seid Ahmad Mousavi in 2007 entitled "an investigation into the role of the financial crisis in forecasting sales and stock returns", the simple linear regression and the multivariate regression with a sample including 106 firms during 1995-2004 have been used to measure the findings where on the role of the financial crisis in forecasting sales and stock returns was taken into account. As a result, combination of the sale factors and indicator of financial crisis lacked of power to define the mean of stock return in studied firms (Mousavi, 2007). An investigation into impact of cash flow stock on return of stock in Companies Listed in Tehran Stock Exchange by Asad Rezaei conducted, where this paper aims to investigate impact of cash flow stock on return of stock in Companies Listed in Tehran Stock Exchange. Hence, 147 companies during 5 years were studied. The results of paper show that change at the rate of cash flow stock includes content of information affecting significantly stock rate of companies whereby decrease of stock rate in the companies would be resulted in the end. Further, the results from the change at rate of cash flow stock in different industries have different impact (Rezaei, 2011).

Ferri and Jones (1979) reported using four measures of business risk and that, despite their apparent appropriateness, significant differences in risk measures were not found among debt ratio classes in the sample studied (Mardgi Gheshmi). Hence Feri and Jones (1979) suggest that firm's size has a significant impact on leverage even though the decisions have been observed to vary among industries.

Bradley and others (1984), who appear to have been misquoted by Titman and Wessels (1988), found that their measure of firm volatility was significant and negatively related to firm leverage ratios. Daniel and Timmermann have provided a paper in 2001 stated that Japanese stock returns are even more closely related to their book-to-market ratios than are their U.S. counterparts, and thus provide a good setting for testing whether the return premia associated with these characteristics arise because the characteristics are proxies for covariance with priced factors. The Daniel and Titman results are clearly controversial; they reject a model that captures the central intuition of traditional asset pricing models in favor of a model that is almost completely ad hoc. Dechow and Dichev's (2002) accrual quality model suggests that the Jones (1991) abnormal accrual model can be improved with the inclusion of past, current, and future operating cash flows. A problem with the empirical implementation of this synthesis is that the augmented accrual model requires future operating cash flow information. An equivalent accrual model that is not subject to the peek ahead and further takes into account the reversal of past accruals has been proposed in his study. This model proposed by him makes a difference in inferences about abnormal accruals of firms with accounting restatements and the market mispricing of abnormal accruals.

Qi Chen and Wei Jiang in a study entitled Analysts' Weighting of Private and Public Information, Used both a linear regression method and a probability-based method, found that on average, analysts place larger than efficient weights on (i.e., they overweight) their private information 
when they forecast corporate earnings. We also find that analysts overweight more when issuing forecasts more favorable than the consensus, and overweight less, and may even underweight, private information when issuing forecasts less favorable than the consensus. Further, the deviation from efficient weighting increases when the benefits from doing so are high or when the costs of doing so are low. These results suggest that analysts' incentives play a larger role in weighting than their behavioral biases (Qi Chen and Wei Jiang, 2005).

\section{Research Questions}

It is asked whether "Sale, Liquidity and Business Risk" affect Stock Returns" at Companies Listed in Tehran Stock Exchange.

\section{Research Hypotheses}

To make clear the research question and also to find to what extent the factors influenced the stock return, the hypothese as follows are proposed including one main hypothesis and three subhypotheses.

\section{The Main Hypothesis}

There is a significant relationship between "Sale, Liquidity and Business Risk" and Stock Returns" at Companies Listed in Tehran Stock Exchange.

\section{The Sub-Hypotheses}

First hypothesis: There is a significant relationship between "Sale" and Stock Returns" at Companies Listed in Tehran Stock Exchange.

First hypothesis: There is a significant relationship between "Liquidity" and Stock Returns" at Companies Listed in Tehran Stock Exchange.

First hypothesis: There is a significant relationship between "Business Risk" and Stock Returns" at Companies Listed in Tehran Stock Exchange.

\section{The Conceptual Research Model}

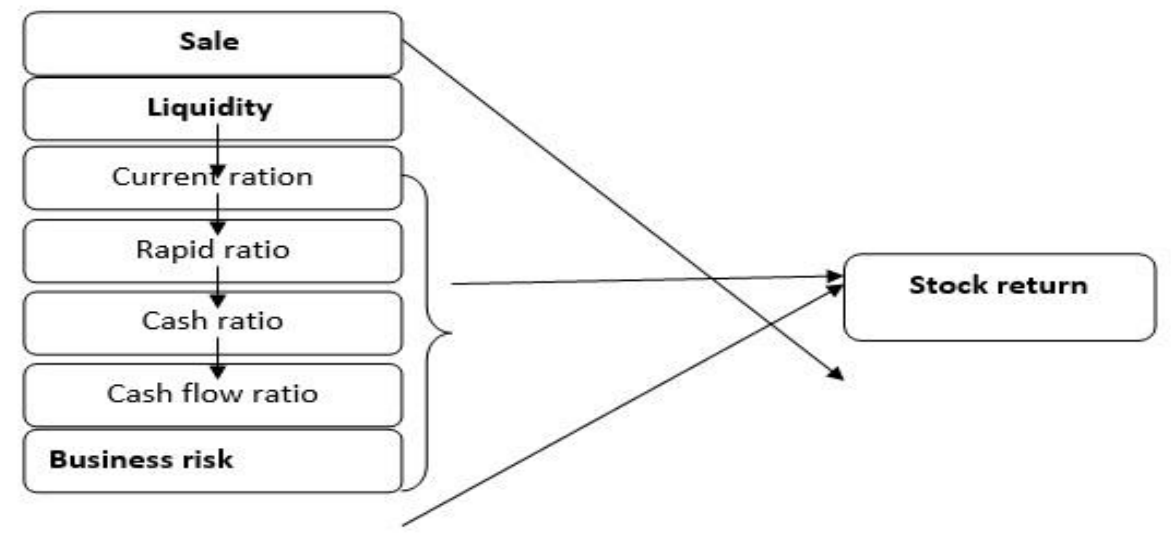

\section{Research Methodology}

Heuristic method is from the correlation type is used in this paper. Further, as the financial information has been used in the process of the research, so the type of paper is an applied type of research. In this paper, adopting information on how to choose the companies working in this field and the indicators associated to this topic 
as well as the financial information about the data needed to test hypotheses have been proposed. On the basis of correlation test, the relationship among the variables of research using correlation coefficient is determined. The correlation research method addresses the limit of changes at one or several variables, aimed to explore the correlation among the variables.

\section{Statistical Population}

Any research on risk and return is conducted based on this presupposition that stock at Companies Listed in Tehran Stock Exchange is transacted. Hence, if stoppage occurs at transaction on the stock of several companies in a long-term, so judging on risk and return would be found with difficulty. Hence, the statistical population of this research has been selected based on two measures:

Companies mentioned have to be members at Companies Listed in Tehran Stock Exchange.

No stoppage seen in Stock trading of companies in a long-term.

Given the conditions above, the number of statistical population is mentioned 426 companies. To select sample, the conditions as follows have been taken:

Till the end of the year 2006, these companies have to be listed in Tehran Stock Exchange and the financial year ends by the year 2006.

The companies have not to change the financial year during the years said.

The company desired has to continue its activities during the research period being conducted where the stock of that transaction has to be taken.

Financial information needed for this research have to be proposed in 2007-2011 in complete.

The companies not to be among the companies invested on stock, relying to profitability is fundamental.
The companies not being included in article 141 of business law.

Profitability: basically, attaining rational relationship between indicators and return for the firms with negative return is not accurate. Companies covered by Article 141 of the Commercial Code: this includes the companies with cumulative retained loss more than half of their capital. The trading symbol of the Companies to fix the problem will be closed on the behalf of the Stock Exchange where no trading conducted in these companies whereby these companies can be accounted as the companies lacked of transaction.

The company without trade during the study period:

A company might not be subjected to Article 141 of the Commercial Code, but, due to several reasons like exclusive conditions and good stock, and etc a transaction might not come to realize and/or just few transactions might occur where these specific transactions accomplish only in a conditions where the price agreed on transaction does not indicate the facts; given that price, the rational decisions on the entire society cannot be taken.

Companies entered into stock recently: The Company with trade during the study period are not of statistical population because the companies are taken which are entered into transaction in each five years. Further, a group of companies with five years' experience and other companies can be less tested because means in this status are calculated not having the opportunity to be compared with each other.

\section{Sample Size and Method of Measurement}

The number of companies selected to conduct the research equals 112 companies. Due to the fact that the stock companies listed in stock exchange of Tehran are totally different from each other in terms of topic and type of activity, thus, the sampling

18 | Page 
method proposed in this paper is the very method of stratified sampling method in order to compare and extrapolate the results of research. This means that the companies which are members at stock exchange of Tehran have been divided into several groups regarding the type of industry where the random sampling method has been used to select the sample.

\section{Tools to Collect Data}

Research data based on the information about the financial statements of companies listed in stock exchange of Tehran exists; further, the data were obtained of journals, publications, magazines and other information existing in library of stock exchange.

- $\quad$ The way to calculate the variables

- $\quad$ The way to calculate the independent variables

Accounting information needed to calculate the independent variables of liquidity and sale, the financial statements of the companies listed in stock exchange during 2007-2011 have been extracted and calculated. Since, the degree of operating leverage show the error level occurring in the profit before interest and tax in order to determine the business risk.

Determine the rate of sale and its impact on changing profit or operating loss is called operating leverage. Measuring susceptibility of profit before interest and taxes of a company to change of sale at that company is called degree of operating leverage. With regard to this measurement, the percentage of change at profit and sale is utilized.

Tax and Interest before profit at change percent/(sale)manufacturing at change percent= degree of operating leverage for $\mathrm{Q}$ manufacturing unit(sale)

Companies affected by the change in sales, which is measured by the degree of operating leverage; this is different at every level of production.
Hence, the value of production where the degree of operating leverage is measured at it has to be obtained.

While this expression is used to detect degree of operating leverage to indicate the value of current sale, the percent of changes in the profit before interest and tax together with sale in the past is applied, but, here the leading point is that the percent of changes at profit before interest and tax in future is examined.

The greater the degree of operating leverage is, the risk of error at predicting profit before interest and tax increases; as a result, the possibility of having the value of profit before interest and tax in a negative increases.

The degree of operating leverage is defined as percent of earnings before interest and taxes to a percentage of changes at production. The degree of operating leverage equals to:

$\mathrm{OL}=(\mathrm{Q}(\mathrm{P}-\mathrm{V})) /(\mathrm{Q}(\mathrm{P}-\mathrm{V})-\mathrm{fc})$

Where OL, Q, P, V, FC respectively indicates operating leverage, the value of production, the prince of sale per each product unit, the changing price of per product, the total fixed prices.

\section{The Way to Calculate the Dependent Variable}

TR in a certain period includes any received cash flow together with the changes in a period to Price bonds or assets at the time of purchase. Total return is calculated as follow: $\mathrm{TR}=$ the cash flow + period in changes at price/ Price bonds or assets at the time of purchase

The total equation to calculate total return is as follows:

$\mathrm{TR}=(\mathrm{CFt}+(\mathrm{PE}-\mathrm{PB})) / \mathrm{PB}=(\mathrm{CFt}+\mathrm{PC}) / \mathrm{PB})$

Where $\mathrm{CFt}, \mathrm{PE}, \mathrm{PB}$ and $\mathrm{PC}$ indicates Cash flows during the period under consideration, Prices in the coming period, The purchase price of the asset or the price at the beginning 
of the period, Price changes during the period, respectively.

\section{Calculation of Total Stock Returns Rit}

Return per share is based on the first and last prices, as well as ownership interests of shareholders in that period are calculated using the following formula:

(Pit-Pit-1+Dit) $/($ Pit-1) $=$ Rit

$\mathrm{t}=$ Rit, $\mathrm{t}=$ Pit, $\mathrm{t}-1=$ Pit -1 and $\mathrm{t}=$ Dit indicates Rate of return on share $\mathrm{i}$ in period, price on share I in the period, the price on share $\mathrm{i}$ in period, interests of shareholders on share i in period. Ownership interests in the period with the Assembly by company awarded to shareholders. Payments to holders of ownership interests in a period decrease the stock price.

Hence, Dit in rate of return can be taken as an adjusting factor. In periods where there is no assembly by company, the value of Dit equals to zero. Dit depending on Community legislation transfers to the stockholders in different forms.

a-The formula to calculate return in payment of Cash Dividends

Rit $=($ Pit-Pit-1+Dit $) /($ Pit-1)

Dit equals to the value of cash dividends.

b- The formula to calculate return in the light of granting award stock

Rit $=((1-\alpha)$ Pit-Pit-1+D $(1+\alpha)) /($ Pit- 1$)$ c- If the general assembly of company issues the increase of capital by $\alpha$ percent, then the formula to calculate each share would be as follows:

Rit $=((1+\alpha)$ Pit $-1-\alpha(1000)+D(1+\alpha)) /($ Pit-

$1+\alpha(1000)$

Percent of the capital increase (priority right): $\alpha$

Nominal value per share: 1000

Relative returns: It is usually necessary to measure the return somewhat different from the total return.

In some cases to go through the calculations, the negative return cannot be used. The relative return resolves this problem by adding the value equals to one to the total return. However, the relative return might be less than one, where its value would be greater than zero; as a result, the negative values would be removed.

The results of calculation and descriptive analysis of research variables

Descriptive analysis addresses investigating central indicators and scattering of research data.

To analyze data, firstly it is essential to calculate the descriptive statistics of data studied in the paper. The main variables of research include return on equity, sales revenue, cash flow and business risk. In table 1 , central indicators and scattering of research data associated to variables of research have been indicated.

Table 1. Descriptive analysis of research variables

\begin{tabular}{cccccc}
\hline Variables & Number & Minimum & Maximum & Mean & $\begin{array}{c}\text { Standard } \\
\text { deviation }\end{array}$ \\
\hline return on equity & 560 & -0.7436 & 7.3414 & 0.320742 & 0.7575374 \\
Sales revenue & 560 & 0.00000 & 5.6704 & 0.872049 & 0.4990126 \\
Current ratio & 560 & 0.2210 & 5.0959 & 1.328881 & 0.6354182 \\
$\quad$ Rapid ratio & 560 & 0.0352 & 5.0926 & 0.815319 & 0.5496604 \\
Upcoming ratio & 560 & 0.0121 & 5.0926 & 0.375419 & 0.5052441 \\
$\quad$ The ratio of & 560 & -60.7870 & 96.2010 & 4.891411 & 18.4101662 \\
working capital & & & & & \\
Business risk & 560 & -91.8830 & 64.8510 & 1.572956 & 8.9562999 \\
\hline
\end{tabular}


Descriptive analysis of research variables has been indicated in table 1 . The entire period research conducted includes five years during 2007-2011. Due to the point that in calculating several research variables the data in period $t-$ 1 is needed, the financial information associated to the year 2006 are gathered. The number of companies applied in this paper consists of 112 companies where the statistical sample includes 560 companies. Descriptive statistics provide the researchers with useful information on the variables calculated. For instance, descriptive statistics show that the companies in sample group during the research period have assigned positive return to the stockholders. Because the mean obtained for each return on share is positive. Further, among liquidity ratios, the ratio of working capital has the highest standard deviation showing the change at the ratio of working capital among the companies involved in sample group.

\section{Evaluation of Normality of Variables}

The test used to measure the hypotheses of research is based on the correlation tests. Normality of variables is one of the primary hypotheses in correlation tests. To investigate normality of variables in inferential statistics, Kolmogorov-Smirnov test (K-S test) is used where this test has been used to investigate the normality of variables in this paper. The statistical hypotheses associated to this test are as follows:

$\mathrm{H}_{0}$ : distribution of data is normal.

$\mathrm{H}_{1}$ : distribution of data is not normal.

The results of statistical test have been shown in table 2.

Table 2 . The test of normality of variables

\begin{tabular}{cccc}
\hline \multirow{2}{*}{ Variables } & \multicolumn{2}{c}{ Kolmogorov-Smirnov test (K-S test) } \\
\cline { 2 - 4 } & $\begin{array}{c}\text { Test } \\
\text { statistics }\end{array}$ & $\begin{array}{c}\text { Freedom } \\
\text { degree }\end{array}$ & Significane level \\
\hline return on equity & 0.168 & 560 & 0.000 \\
Sales revenue & 0.139 & 560 & 0.000 \\
Current ratio & 0.168 & 560 & 0.000 \\
Rapid ratio & 0.16 & 560 & 0.000 \\
Upcoming ratio & 0.236 & 560 & 0.000 \\
The ratio of working & 0.219 & 560 & 0.000 \\
capital & 0.269 & 560 & 0.000 \\
Business risk & & &
\end{tabular}

According to the results proposed in table 2, the significance level obtained of Kolmogorov-Smirnov test (K-S test) for the entire variables is less than the error level of test $(\alpha=0.05)$. In this regards, $\mathrm{H}_{0}$ is rejected and the values associated to the research variables would not follows the normal distribution. Hence, nonparametric tests have to be used in investigating the correlation existing among the variables.

\section{The Results from the First Hypothesis Test}

With regard to first hypothesis, it has been forecasted that there is a significant relationship between sale and return on stock at Companies Listed in Tehran Stock Exchange. Due to not having the normal variables, Spearman's Correlation Coefficient has been used to test the hypotheses. Spearman's Correlation Coefficient is a test using to investigate the relationship existing among the variables which are not normal. According to what said in the hypothesis, the statistical 
hypotheses as follows can be taken into account.

$\mathrm{H}_{0}: \mathrm{r}=0$

$\mathrm{H}_{1}: \mathrm{r} \neq 0$

In other words, the first research hypothesis is confirmed while the correlation coefficient among the variables proposed in this hypothesis not to be equal to zero. The results from the investigation of the relationship between return on stock and earning of sale have been proposed in correlation matrix.

Table 3. The results for statistical analysis to test first hypothesis (relationship between return on stock and earning of sale)

\begin{tabular}{|c|c|c|c|}
\hline & & return on stock & $\begin{array}{l}\text { earning of } \\
\text { sale }\end{array}$ \\
\hline \multirow[t]{3}{*}{ return on stock } & $\begin{array}{c}\text { Spearman's Correlation } \\
\text { Coefficient }\end{array}$ & 1.000 & $0.120^{* *}$ \\
\hline & Significance level & 0 & 0.004 \\
\hline & $\begin{array}{c}\text { Number of } \\
\text { observations }\end{array}$ & 560 & 560 \\
\hline \multirow[t]{3}{*}{ earning of sale } & $\begin{array}{c}\text { Spearman's Correlation } \\
\text { Coefficient }\end{array}$ & $0.120^{* *}$ & 1.000 \\
\hline & Significance level & 0.004 & 0 \\
\hline & $\begin{array}{l}\text { Number of } \\
\text { observations }\end{array}$ & 560 & 560 \\
\hline **. Correl & is significant at the $0.01 \mathrm{l}$ & el (2-tailed). & \\
\hline
\end{tabular}

The results from correlation analysis indicate that the correlation coefficient and significance level equals to 0.120 and 0.004 , respectively; here, the significance level is less than error level of test (0.05). This finding indicates that a direct significant relationship exists between return on stock and earning of sale, indicating the more the sale increases at companies listed in stock exchange, the return on stock increases as well. In this regards, $\mathrm{H}_{0}$ is rejected and significant relationship among the variables is confirmed. This finding is relevant with the first hypothesis of research whereby the hypothesis is confirmed at $95 \%$ significance level.

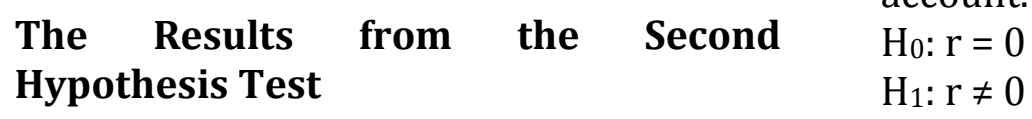

With regard to second hypothesis, it is assumed a significant relationship exists between liquidity and return on stock at companies listed in stock exchange. In present paper, current ratio, quick ratio, quick ratio and working capital ratio have been taken into account as the liquidity measures at the companies regarded in statistical sample. Due to not having the normal variables, Spearman's Correlation Coefficient has been used to test the hypotheses. Spearman's Correlation Coefficient is a test using to investigate the relationship existing among the variables which are not normal. According to what said in the hypothesis, the statistical hypotheses as follows can be taken into account.

$\mathrm{H}_{1}: \mathrm{r} \neq 0$ 
In other words, the second research hypothesis is confirmed while the correlation coefficient among the variables proposed in this hypothesis not to be equal to zero. The results from the investigation of the relationship between liquidity and return on stock at companies listed in stock exchange.

Table 4. The results for statistical analysis to test second hypothesis (relationship between liquidity and return on stock at companies listed in stock exchange)

\begin{tabular}{|c|c|c|c|c|c|c|}
\hline & & $\begin{array}{c}\text { return } \\
\text { on } \\
\text { stock }\end{array}$ & $\begin{array}{l}\text { current } \\
\text { ratio }\end{array}$ & $\begin{array}{l}\text { quick } \\
\text { ratio }\end{array}$ & $\begin{array}{l}\text { quick } \\
\text { ratio }\end{array}$ & $\begin{array}{l}\text { working capital } \\
\text { ratio }\end{array}$ \\
\hline \multirow{3}{*}{ return on stock } & $\begin{array}{c}\text { Spearman's Correlation } \\
\text { Coefficient }\end{array}$ & 1.000 & $0.172^{* *}$ & $0.173^{* *}$ & 0.000 & $0.096^{* *}$ \\
\hline & Significance level & 0 & 0.000 & 0.000 & 0.990 & 0.024 \\
\hline & Number of observations & 560 & 560 & 560 & 560 & 560 \\
\hline \multirow{3}{*}{ current ratio } & $\begin{array}{c}\text { Spearman's Correlation } \\
\text { Coefficient }\end{array}$ & $0.172^{* *}$ & 1.000 & $0.747^{* *}$ & $\begin{array}{l}0.267 \\
* *\end{array}$ & $0.126^{* *}$ \\
\hline & Significance level & 0.000 & 0 & 0.000 & 0.000 & 0.003 \\
\hline & Number of observations & 560 & 560 & 560 & 560 & 560 \\
\hline \multirow{3}{*}{ quick ratio } & $\begin{array}{c}\text { Spearman's Correlation } \\
\text { Coefficient }\end{array}$ & $0.173^{* *}$ & $0.747^{* *}$ & 1.000 & $\begin{array}{c}0.458 \\
* *\end{array}$ & $0.086^{*}$ \\
\hline & Significance level & 0.000 & 0.000 & 0 & 0.000 & 0.044 \\
\hline & Number of observations & 560 & 560 & 560 & 560 & 560 \\
\hline \multirow{3}{*}{ quick ratio } & $\begin{array}{c}\text { Spearman's Correlation } \\
\text { Coefficient }\end{array}$ & 0.000 & $0.267^{* *}$ & $0.458^{* *}$ & 1.000 & 0.010 \\
\hline & Significance level & 0.990 & 0.000 & 0.000 & 0 & 0.822 \\
\hline & Number of observations & 560 & 560 & 560 & 560 & 560 \\
\hline \multirow{4}{*}{$\begin{array}{c}\text { working } \\
\text { capital ratio }\end{array}$} & $\begin{array}{c}\text { Spearman's Correlation } \\
\text { Coefficient }\end{array}$ & $0.096^{*}$ & $0.126^{* *}$ & $0.086^{* *}$ & 0.010 & 1.000 \\
\hline & Significance level & 0.024 & 0.003 & 0.044 & 0.822 & 0 \\
\hline & Number of observations & 560 & 560 & 560 & 560 & 560 \\
\hline & $\begin{array}{l}\text { **. Correlation is sign } \\
\text { *. Correlation is signi }\end{array}$ & $\begin{array}{l}\text { cant at } \\
\text { ant at } t\end{array}$ & the 0.01 & $\begin{array}{l}\text { el }(2-t a \\
\text { el }(2-t a i\end{array}$ & & \\
\hline
\end{tabular}

The results from correlation analysis indicate that the correlation coefficient for current ratio, quick ratio, quick ratio and working capital ratio is positive and significant. This finding indicates a direct significant relationship between liquidity ratio mentioned above and the return on stock at companies taken in sample group. While the significant level of correlation test on the quick ratio equals to 0.05, indicating no significant relationship between this variables and return on stock. These findings show that Investors and capital market participants potentially take into their account the capability of liquidity of companies chosen as sample group whereby the financial information of these companies more likely is taken and analyzed in adopting investing decisions. According to the significant relationship among three ratios of the liquidity ratios studied in this paper, what 
said in second hypothesis based on the significant relationship between return on stock and liquidity can be approved. In this regards, the second hypothesis is approved and accepted at 95\% significance level.

\section{The Results from the Third Hypothesis Test}

With regard to third hypothesis, it is assumed a significant relationship exists between business risk and return on stock at companies listed in stock exchange. Due to not having the normal variables, Spearman's Correlation Coefficient has been used to test the hypotheses. Spearman's Correlation Coefficient is a test using to investigate the relationship existing among the variables which are not normal. According to what said in the hypothesis, the statistical hypotheses as follows can be taken into account.

$\mathrm{H}_{0}: \mathrm{r}=0$

$\mathrm{H}_{1}: \mathrm{r} \neq 0$

In other words, the third research hypothesis is confirmed while the correlation coefficient among the variables proposed in this hypothesis not to be equal to zero. The results from the investigation of the relationship between business risk and return on stock at companies listed in stock exchange have been proposed as follows.

Table 5. The results for statistical analysis to test third hypothesis (relationship between business risk and return on stock at companies listed in stock exchange)

\begin{tabular}{cccc}
\hline & & $\begin{array}{c}\text { Return on } \\
\text { stock }\end{array}$ & Business risk \\
\hline $\begin{array}{c}\text { Return on } \\
\text { stock }\end{array}$ & $\begin{array}{c}\text { Spearman's } \\
\text { Correlation } \\
\text { Coefficient } \\
\text { Significance level } \\
\text { Number of } \\
\text { observations } \\
\text { Spearman's }\end{array}$ & 1.000 & 0.033 \\
& $\begin{array}{c}\text { Correlation } \\
\text { Coefficient } \\
\text { Business risk }\end{array}$ & 0.033 & 0.440 \\
& $\begin{array}{c}\text { Significance level } \\
\text { Number of } \\
\text { observations }\end{array}$ & 0.440 & 0 \\
\hline
\end{tabular}

The results from correlation analysis indicate that the significance level equals to 0.44; here, the significance level is greater than error level of test (0.05). This finding indicates that a significant relationship does not exist between return on stock and business risk. In other words, these findings show that Investors and capital market participants potentially have not taken into their account the business risk of companies chosen as sample group whereby the information on business risk have not taken in decisions on investing.

With regard to the results proposed in table 5, the statement on third hypothesis based on the relationship between return on stock and business risk cannot be accepted. In this regards, the hypothesis above is rejected at 95\% significance level. 


\section{A Summary of Results of Hypotheses Testing}

Present paper aimed to investigate the relationship between Sale, Liquidity and
Business Risk and Stock Returns at Companies Listed in Tehran Stock Exchange, in this paper, three hypotheses have been proposed, investigated through the Spearman's Correlation Coefficient.

Table 6. The results of statistical analyses on the research hypotheses have been proposed

\begin{tabular}{|c|c|c|c|c|c|}
\hline $\begin{array}{c}\text { Summary of } \\
\text { hypothesis }\end{array}$ & Variable & Type of test & $\begin{array}{l}\text { The value of } \\
\text { correlation } \\
\text { coefficient }\end{array}$ & $\begin{array}{c}\text { Significance } \\
\text { level }\end{array}$ & Result \\
\hline $\begin{array}{l}\text { Confirming } \\
\text { the hypothesis }\end{array}$ & $\begin{array}{l}\text { Earning of } \\
\text { sale }\end{array}$ & $\begin{array}{l}\text { Spearman's } \\
\text { Correlation } \\
\text { Coefficient }\end{array}$ & 0.12 & 0.004 & $\begin{array}{l}\text { a significant } \\
\text { relationship } \\
\text { exists between } \\
\text { sale and return } \\
\text { on stock at } \\
\text { companies } \\
\text { listed in stock } \\
\text { exchange }\end{array}$ \\
\hline $\begin{array}{l}\text { Confirming } \\
\text { the hypothesis }\end{array}$ & $\begin{array}{c}\text { Current ratio } \\
\text { Quick ratio } \\
\text { Quick ratio } \\
\text { working } \\
\text { capital ratio }\end{array}$ & $\begin{array}{l}\text { Spearman's } \\
\text { Correlation } \\
\text { Coefficient }\end{array}$ & $\begin{array}{l}0.171 \\
0.173 \\
0.000 \\
\\
0.096\end{array}$ & $\begin{array}{l}0.000 \\
0.000 \\
0.999\end{array}$ & $\begin{array}{l}\text { a significant } \\
\text { relationship } \\
\text { exists between } \\
\text { liquidity and } \\
\text { return on stock } \\
\text { at companies } \\
\text { listed in stock } \\
\text { exchange }\end{array}$ \\
\hline $\begin{array}{l}\text { Rejecting the } \\
\text { hypothesis }\end{array}$ & business risk & $\begin{array}{l}\text { Spearman's } \\
\text { Correlation } \\
\text { Coefficient }\end{array}$ & 0.033 & 0.44 & $\begin{array}{l}\text { a significant } \\
\text { relationship } \\
\text { exists between } \\
\text { business risk } \\
\text { and return on } \\
\text { stock at } \\
\text { companies } \\
\text { listed in stock } \\
\text { exchange }\end{array}$ \\
\hline
\end{tabular}

In present paper, the relationship between several measures of efficiency and return on stock was examined. In accordance with findings, investors and capital market participants to have reacted to the amount of sale and liquidity reported at the companies listed in stock exchange. While the capital market has not drawn into attention the business risk at the companies, whereby other measures are taken in measuring the risk existing at companies.

\section{Conclusion}

The results of paper show that investors and capital market participants to have reacted to the amount of sale and liquidity ratios at the companies listed in stock exchange. While the capital market has not drawn into attention the business risk at the companies, whereby other measures are taken in measuring the risk existing at companies.

\section{Suggestions}

1-It is recommended to the stock companies pay attention to the information needed for investors, attempting to provide the financial information of the company in accordance with the needs whereby the highest efficiency on informing the investors and enhancing the transparency of information would come to realize. 
2- It is recommended to the stock companies pay attention to the results of research and similar studies, attempting to enhance the measures such as the amount of sale and power of liquidity at the company. Because as proved, the return on stock at the companies with higher sale and liquidity would be greater.

3 - It is recommended to the investors pay attention to information which can be directly provided for them, attempting to analyze and measure other financial information and calculate more measures. In this context, not being provided with sufficient knowledge and proficiency can be utilized of the consultancy services on investing.

\section{References}

Abbasnejad, A.A. (2002). Financial analysis of companies in Tehran Stock Exchange based on hierarchy process (AHP) limited to motor vehicles and transportation companies, MS Thesis, University of Imam Sadiq (AS), Faculty of Education of management.

Ball R. and Brown L. (1968). Earnings Quality at Initial Public Offerings. Journal of Accounting and Economics forthcoming.

Chen, Q. and Jiang, W. (2005). Analaysts' Weighting of Private and Public Information, Journal of accounting and Economics.

Dechow and Dichev, I. (2002). The quality of accrual and earnings: The role of accrual estimation error, The Accounting Review, 77.

Douglas J. and Skinner (2004). What Do Dividends Tell Us About Earnings Quality?January, SSRN Website.

Ismaili, Sh. (2006). The relationship between earnings quality and stock returns, Master Thesis in Accounting, Allameh Tabatabai University, School of management accounting.

Jamali, F. (2003). Relationship between Capital Structure and Cash Flows food Tehran Stock Exchange, MS Thesis accounting university, faculty of social and economic sciences.

Jones, Ch.P. (2011). Investment management, Trans doctor Reza Tehrani, Seventh Edition, published by Negah Danesh publication.

Jhankhany, A. and Parsaeian, A. (1995). Stock Exchange, first edition, published by Faculty of Management, Tehran.

Khaki, G.R. (1999). Method approach to the research dissertation, Tehran, center for Scientific Research.

Dastgir, M. (2010). Fundamentals of Financial Management, Volume I, Fourth Edition, Tehran, Nourpardazan.

Dastgir, H. and Zafari, F. (2009). The role of accounting information in predicting stock returns, Humanities and Cultural Studies, Integrated Humanities Center, No. 85, September.

Ranjbar Kohan, M. (2007). Evaluation of commercial risk and liquidity on dividends of listed companies in Tehran Stock Exchange, Thesis Master of Business Administration, University, School of Management, Central Tehran Branch.

Rezaee, A. (2011). An investigation into the effect of changes at return on stock at listed companies in Tehran Stock Exchange, the Financial Accounting Research, No. III, Volume III, Fall.

Salimi Pour, M. (2005). The effect of stock liquidity on excess stock returns accepted 
companies in Tehran Stock Exchange, MS Thesis Accounting, Tehran University.

Mardegi Gheshmi, R. (2002). Relationship between changes in stock prices and financial Nsbnhay accepted companies in Tehran Stock Exchange, MS Thesis, accounting, Shiraz University.

Mousavi, S.A. (2007). Study the factors influencing growth of sales and financial crisis indicators in predicting stock returns, Journal of Economics, studies of accounting and auditing, No. 47, Spring.

Jeffrey D., Weili G., and Mc Vay, S. (2005). Accruals quality and internal control over financial reporting.
Daniel, K.D. and Timmermann, A. (2001). Investor Psychology and security market under- and over- reactions, Journal of Finance.

Dilluichy W.J. (2004). Efficient market hypothesis and forecasting", International Journal of Forecasting 20.

O'conner, M.C. (1973). On the Usefulness of Financial Ratios to Investors in Commom Stock, The Accounting Review, April.

Salmi,T., Virtanan, J., and Yli-Olli, P. (1997). The General Association Between Financial Statement and Security Characteristics, Scand.J.Mgmt, vol. 13, No.2.

How to cite this article: Mahdi Bagheri, Abolghasem Gholamreza Tehrani, Elham Niromand Vojdani aval, A Survey on the Relationship between Sale, Liquidity and Business Risk with Stock Returns at Companies Listed in Tehran Stock Exchange. International Journal of Advanced Studies in Humanities and Social Science, 2019, 8(1), 13-27. http://www.ijashssjournal.com/article 84106.html 